\title{
Audio-visual Metaphors of the Financial Crisis: Meaning Making and the Flow of Experience
}

\section{Metáforas audiovisuais da crise financeira: a construção do significado e o fluir da experiência}

\author{
Cornelia Müller* \\ Faculty of Social and Cultural Sciences, European University Viadrina \\ Frankfurt/Oder / Germany \\ Christina Schmitt** \\ Department for Film Studies, Freie Universität Berlin, Germany \\ Berlin / Germany
}

\begin{abstract}
This paper advocates a perspective on metaphors in audio-visual media that conceives of these as processes of meaning making, i.e., as dynamic embodied conceptualizations, constitutively bound to the flow of experience. This involves experience in a double sense: as immediate affection through an audio-visually orchestrated form of movement experience and as sensory-motor experiences of metaphoric source domains. Drawing on an interdisciplinary (linguistic and film analysis) method, this study presents an analysis of a German political TV report on winners and losers of the financial crisis. The goal of this case study is twofold: to reconstruct the complexity of metaphoric meaning making in audio-visual media and to illustrate a theoretical claim: that metaphors in audio-visual compositions emerge dynamically from sensory and affective experiences.

KEYWORDS: audio-visual metaphor; cinematic expressive movement; dynamics of metaphor; meaning making; metaphor and experience; metaphoric theme; emergence of metaphor.
\end{abstract}

\footnotetext{
*cmueller@europa-uni.de

** christina.schmitt@fu-berlin.de
} 
RESUMO: Esse trabalho defende uma perspectiva da metáfora nos meios audiovisuais, que entende tal processo como construção do significado, i.e., como conceitualizaçóes corporificadas dinâmicas, associadas no seu cerne ao fluir da experiência. Isso envolve experiência em duplo sentido: como afeição imediata por meio de uma forma audiovisual orquestrada de experiência do movimento e como experiências sensório-motoras de domínios-fonte metafóricos. A partir de um método interdisciplinar (linguístico e análise de filme), este estudo apresenta a análise de um programa de TV sobre política alemã, que aborda o tema das perdas e ganhos na crise financeira. São dois os objetivos deste estudo de caso: reconstruir a complexidade da construção do significado metafórico na mídia audiovisual e ilustrar uma questão teórica: que metáforas em composiçóes audiovisuais emergem de forma dinâmica a partir de experiências sensórias e afetivas.

PALAVRAS-CHAVE: metáforas audiovisuais; movimento expressivo cinemático; dinâmica da metáfora; construção de significado; metáfora e experiência; temática metafórica; emergência da metáfora.

\section{Introduction}

This paper seeks to outline, how a dynamic view on metaphor opens a specific means through which to address meaning making in audio-visual media. More specifically, the authors, advocate a perspective on audiovisual metaphors that conceives of these as processes: as dynamic embodied conceptualizations, which are constitutively bound to the flow of experience. Therefore, this work seeks to address a facet of audio-visual metaphors that Lakoff and Johnson (1980, p. 5, italics made by authors) formulated early on with regard to metaphor and language: "the essence of metaphor is understanding and experiencing one kind of thing in terms of another."

With the notion of "understanding and experiencing" in their meanwhile canonical statement, Lakoff and Johnson (1980) (implicitly) formulated the concept of metaphor in a triadic structure, which is a constant trait in the scholarly reflections upon the very nature of metaphor (MÜLLER, 2008a, p. 26-32, 114-133). More importantly for the argument presented here is that by choosing the term 'conceptual' as an attribute to their theory of metaphor, the 'understanding' part of this statement was highlighted - that metaphors are part of our conceptual system and that they structure the mundane ways of understanding the world we inhabit. It is this very focus which this paper seeks to reverse, by departing from the experiencing side of metaphor and suggesting that it is a specificity of audio-visual metaphors to be grounded in affective experiences evoked by 
the moving nature of audio-visual images. It is, therefore, suggested that audio-visual metaphors involve 'experience' in a double sense: an immediate affection through the dynamic orchestration of audio-visual compositions, i.e., a temporally organized form of movement experience (KAPPELHOFF, 2004), and a sensory-motor experience of metaphoric source domains, i.e., as activation of metaphoricity (MÜLLER, 2008a). The domains of metaphors are thus considered to be realms of experience, which are not bound to any form of modality. Establishing, creating, and finding metaphors is regarded as a process in which one domain of experiences is seen and felt in terms of another domain of experiences. This is a core assumption of a dynamic view of metaphor (MÜLLER, 2008b). Metaphor is, in this view, a matter of meaning making over time; it is a temporal structure that is dynamic and unfolding. As such, metaphors may extend over a TV show, a news report, or a film; they emerge and unfold and may even structure the audio-visual composition as a whole.

Such a dynamic view on metaphors - as they appear in all kinds of multimodal forms of discourses (KAPPELHOFF \& MÜLLER, 2011; MÜLLER, 2011; MÜLLER \& CIENKI, 2009) - contributes more generally to metaphor research in discourse analysis (for an overview see Semino, 2008; Musolff \& Zinken, 2009). In particular, this concerns meaning construction (BRANDT \& BRANDT, 2005a, b), extendedness (WERTH 1994, CRISP, 2008), temporality, situatedness, and embodiment of metaphor (ZINKEN, HELLSTEN \& NERLICH, 2008). The dynamic view on metaphors advocated in this article is especially in harmony with Cameron's discourse dynamics approach to metaphor (CAMERON, 2011). It follows a similar understanding of how metaphor works and emerges from discourses rather than being instantiated in words or images. However, in contrast to Cameron's focus on linguistic metaphor, the dynamic view on metaphor inherently addresses the multimodal nature of metaphoric meaning making in communication. It doing so, it shifts scope, as it assumes that multimodal metaphors (audio-visual metaphors in particular) involve an actual experiencing of metaphoricity and not only a potential emergence of discourse metaphor, as is assumed by Cameron's approach. A theoretical and methodological consequence of the dynamic perspective on audiovisual metaphors being advocated herein is that our analyses only consider those verbal metaphoric expressions that are activated by audio-visual concretizations andlor elaborations of their experiential source domains. In this 
respect, the activation approach to metaphor 'identification' differs from Cameron's idea of collecting and grouping all potentially metaphoric vehicle terms articulated verbally (CAMERON \& MASLEN, 2010). Cameron's discourse metaphors are built on these groupings of verbal metaphoric expressions, and she herself underlines the potentiality of the metaphoric meaning being reconstructed in this way. Furthermore, our dynamic view (including the focus on activated metaphoricity) also differs from the more 'static' view favored by the Metaphor Identification Procedure (MIP) (PRAGGLEJAZ GROUP, 2007; including a variant of MIP formulated by a group of scholars at VU University Amsterdam (MIPVU), STEEN ET AL., 2010), by which the potential metaphoricity of each and every word in a given text is analyzed. It is important to note that, for MIP and MIPVU, the decision of whether a given word is considered metaphoric or not is based on a corpus-based dictionary: if the entry for a given potential metaphor contains one more basic and one more abstract meaning and if the context of the use of the potential metaphoric word favors a more abstract reading, then the term is considered metaphoric (PRAGGLEJAZ GROUP, 2007).

On the other hand, what our approach shares with Cameron's discourse metaphor, as well as with the MIP/MIPVU, is the caution that should be taken regarding claims about psychological processing. Cameron's identifying and grouping each and every metaphoric expression in a discourse does not allow her to draw conclusions about the psychological processing of metaphoric meaning. With MIP/MIPVU, again no assumptions are being made concerning psychological processing, yet by relying on a corpus-based dictionary there is at least the implicit assumption that words with a 'double' meaning (one more basic and one more abstract) are used and understood metaphorically in the given language-community. The reference to the activation of metaphoricity, however, does not consider the psychological claims concerning metaphor processing. What is claimed, though, is that activated metaphoricity appears in a communicative effort (MÜLLER \& TAG, 2010) of foregrounding these metaphors and making metaphoric source domains a vital source of experiences.

Moreover, it is important to bear in mind, that the 'data' being examined in this study differs from the data analyzed with MIP/MIPVU or with Cameron. While their method only targets verbal metaphor, the activation approach addresses multimodal metaphors in both audio-visual formats as well as in speech and gesture. Moreover, this difference in data 
has a direct impact on the theoretical framing of the nature and notion of metaphor. There are two general aspects of audio-visual media that we assume to afford particular theoretical and methodological resonance namely that the audio-visual image is an inherently temporal and multimodal phenomenon (SCHERER, GREIFENSTEIN \& KAPPELHOFF, 2014, p. 2088-89). As a consequence, we conceive of verbal language as only one contributing aspect to audio-visual metaphors. Moreover, analyzing metaphors in audio-visual media shows that linguistic metaphors are only the tip of the iceberg regarding the multitude of ways in which metaphoric meaning making can occur. It is by locating metaphoric meaning making in a process of seeing and feeling one type of thing in terms of another that we extend the scope of metaphor from the realm of language to a realm in which multiple modalities interact (MÜLLER, 2008a, p. 22-39; KAPPELHOFF \& MÜLLER, 2011; SCHMITT, GREIFENSTEIN \& KAPPELHOFF, 2014; KAPPELHOFF \& GREIFENSTEIN in prep.; SCHMITT in prep.). Against this background, it is suggested that audio-visual metaphors are grounded both in embodied (metaphoric) conceptualizations and in the flow of experiences of moving images. Furthermore, the very ways in which audio-visual metaphors are staged and orchestrated temporally makes some more prominent and more vital than others.

To conceive of audio-visual metaphors as temporal and emergent structures and as dynamic forms of meaning making also differs from a more 'static' and 'top-down' Conceptual Metaphor Theory approach to metaphors in audio-visual media research, addressing fiction film, advertisement, and news coverage (COËGNARTS \& KRAVANJA, 2012; FAHLENBRACH, 2007, 2010; FORCEVILLE, 2007; FORCEVILLE \& APARISI, 2009; ORTIZ, 2014; WINTER, 2014). While research in this vein is especially interested in discovering instantiations of conceptual metaphors in a wide range of audio-visual formats, the present study seeks to reconstruct the dynamic emergence of metaphoric meaning through the temporal orchestration of audio-visual compositions (KAPPELHOFF \& MÜLLER, 2011; SCHMITT, GREIFENSTEIN \& KAPPELHOFF, 2014). Essentially, this involves a 'bottom-up' and 'dynamic' perspective. As a consequence, the metaphors formulated herein are 'closer' to the data. They are more specific and their formulation is grounded in the audio-visual composition itself. Typically, the dynamic metaphors are therefore more specific than formulations of conceptual metaphors. Put differently, the audio-visual 
metaphors analyzed in this study are explicitly not generalizable; they are specific, emergent, and experienced.

The take on audio-visual metaphor followed in this paper is an emphatically interdisciplinary venture, as it brings together Kappelhoff's film-analytic approach to "cinematic expressive movement" (KAPPELHOFF, 2004; KAPPELHOFF \& BAKELS, 2011; KAPPELHOFF \& MÜLLER, 2011; SCHERER, GREIFENSTEIN \& KAPPELHOFF, 2014) with Müller's cognitive-linguistic view on the "dynamics of multimodal metaphor” (MÜLLER, 2008a, 2008b, 2011; MÜLLER \& TAG, 2010). This study thus begins by confronting the following assumptions: audiovisual metaphors are dynamic and they are dynamic forms of meaning making grounded in the flow of affective experiences of moving images.

The present paper will illustrate this assumption by analyzing a TV report on the financial crisis, taken from a monthly political show on German national television. ${ }^{1}$ The TV report by Gottlob Schober and Steffen Hudemann comes from the German political broadcast Report Mainz (shown on German national TV, ARD, October 20, 2008) ${ }^{2}$ and develops within its six and a half minutes an argumentation about who the winners or the losers of the banking crisis are, respectively, and why this is so. With regard to metaphoric meaning making, something interesting happens in the very beginning of the introduction to the magazine. There, the presenter verbally sets up the dominant metaphoric opposition for the entire audio-visual composition, in which winners and losers of the banking crisis are arranged on a vertical axis: "winners are up and losers are down." Having briefly described the bankers' responsibility for the financial crisis, the presenter mentions Josef Ackermann, the, at the time, highly prominent Chairman of the Management Board and the Group Executive Committee

\footnotetext{
${ }^{1}$ This analysis is an outcome of collaborative research conducted within the interdisciplinary project "Multimodal Metaphor and Expressive Movement" ("Multimodale Metaphorik und Ausdrucksbewegung", 2009-2013) under the direction of Hermann Kappelhoff and Cornelia Müller at the Cluster of Excellence "Languages of Emotion" of the Freie Universität Berlin in cooperation with the European University Viadrina Frankfurt (Oder). We particularly would like to thank our project colleagues Hermann Kappelhoff, Susanne Tag and Sarah Greifenstein for their contributions to earlier versions of this work, from which our analysis has strongly benefited.

${ }^{2}$ This is also the source for all screenshots (made by the authors) that are part of the later Figures in Section 3.
} 
of the Deutsche Bank (2006-2012). Particularly, Ackermann's 'generous' million-waiver "for the benefit of well-respected and deserving employees" is mentioned. Additionally, he is characterized as being part of a "lifted monetary caste":

"What is true is that Mister Ackermann's million-waiver 'for the benefit of deserving employees' is a sign of loss of reality of a completely lifted monetary caste."

["Richtig ist, dass der Millionenverzicht des Herrn Ackermann 'zugunsten verdienter Mitarbeiter' ein weiteres Indiz für den Realitätsverlust einer völlig abgehobenen Geldkaste ist."] (transcribed from Report Mainz)

Referring to bankers as "lifted monetary caste" sets up metaphoric mappings between being a successful bank manager and being 'up', which could be interpreted as an instantiation of an Orientational Conceptual Metaphor that organizes successful and unsuccessful experiences along a vertical axis (LAKOFF \& JOHNSON, 1980, p. 14-21; DIJKSTRA et al., 2014; GIBBS, 2009, p. 25-26; LUODONPÄÄ-MANNI \& VIIMARANTA, 2010; SANTANA \& DE VEGA, 2011). In this study, however, it is argued that there is more going on than a conceptual arrangement along a vertical axis of a single metaphoric expression. Rather, this first mentioning of the verticality axis is the onset of an emergent embodied metaphoric structure that dynamically organizes the composition of the entire TV report by offering dynamically unfolding realms of metaphorically mediated experiences.

It is important to note that the presenter closes his introduction by further elaborating the metaphoric verticality axis: he sets up an opposition in which, to the spectators' surprise, bankers are described as losers of the financial crisis, and those losing bankers are metaphorically described as 'fallen' bankers, setting up a semantic opposition between winning bankers that are 'up' and losing bankers that are 'down'. This rhetorical twist is further highlighted by characterizing, metaphorically, the fall of the bankers as being gentle. Which, of course, implies that 'non-banker' losers in the financial crisis fall anything but gentle.

"Some people may take comfort in the fact that many a banker has to leave his executive chair now. But don't cheer to soon: many fired bankers will fall gently, if they fall." 
["Da mag sich der eine oder andere freuen, dass so mancher Banker den Chefsessel nun räumen muss. Doch nicht zu früh gefreut: viele der gefeuerten Banker werden, wenn sie fallen, weich fallen."] (transcribed from Report Mainz)

This is considered an activation of a metaphoric source domain achieved by a semantic opposition and an elaboration of metaphoric meaning. The rhetoric effect of this introduction is that the spectator's attention is guided towards this specific and uncommon interpretation of the social position of bankers in the financial crisis, most of whom are winners, but some of whom are also losers in the crisis. Nevertheless, even if they are losers, they are the better losers, because their fall has been 'softened'.

By setting up the metaphoric opposition of winners as being lifted and losers as falling, the introduction sets up the frame for the report as a whole: because it guides the spectators attention to the cinematic orchestration of what will turn out to be the 'experiential realm' of the report. The introduction sets up the domain of experiences for the embodied conceptualizations of the financial crisis, which will dynamically structure the audio-visual composition. In doing so, the metaphoric oppositional structure will be made 'experientially' available and will be refined by certain affective qualities that are evoked through the cinematic composition, specifically by cinematic expressive movements.

To sum up, the introduction to the report already sets up the metaphoric oppositional structure that will be elaborated conceptually and grounded in actual sensory experiences throughout the report. The two contrasting metaphors that will emerge over the course of the overall audiovisual composition can be formulated as follows:

Winning in the financial crisis is experienced and understood as being lifted and up, closed and inside, excluding the outside, moving fast, straight, and unaffected.

Losing in the financial crisis is experienced and understood as falling and being down, outside, and excluded, as stopping to move.

A methodological outline will precede the further elaboration of these first observations. 


\section{Analyzing audio-visual metaphors and their embodied temporal dynamics - methodological outline}

Our analysis targets two core dimensions of how audio-visual metaphors create a dynamic, temporally-orchestrated, and thus experientially grounded way of understanding through experience. This is reflected in the methodological approach to "Metaphors in audio-visuals" (see also Schmitt, Greifenstein \& Kappelhoff, 2014). In this paper, film-analytical and cognitive-linguistic analyses are combined with two methodological foci:

(A) Composition of cinematic expressive movements as immediate affection (KAPPELHOFF, 2004; KAPPELHOFF \& BAKELS, 2011; KAPPELHOFF \& MÜLLER, 2011; SCHERER, GREIFENSTEIN \& KAPPELHOFF, 2014);

(B) Activation of metaphoricity through the elaboration of experiential source domains of metaphors (MÜLLER, 2008a, 2008b, 2011; MÜLLER \& TAG, 2010).

Notably, these two aspects of audio-visual movement-images are only analytically separated, they are not ontologically distinct.

\section{(A) Cinematic expressive movement}

Cinematic expressive movements are distinctive temporal gestalts that are characterized by a specific expressive quality. Kappelhoff's notion of cinematic expressive movement captures a form of audio-visual expressivity that is comparable to bodily expressivity. He argues that audio-visual compositions are structured temporally in forms of movement-gestalts that can be compared to the temporal unfolding and gestalts of facial expressions. Much like a smiling face is immediately perceived as an affective experience, a cinematic expressive movement is also perceived as an affective experience. However, as much as facial expressions or gestures are conceived as paradigmatic expressive movements within the theory of expression (LESSING, 1954; BÜHLER, 1968; PLESSNER, 1982; for an overview, see also Greifenstein \& Kappelhoff, 2014), it would fall far too short to restrict the phenomenon to a visually perceivable movement. By contrast, as Scherer, Greifenstein, and Kappelhoff (2014) point out, cinematic expressive movements "realize their gestalts by addressing all senses of $[\ldots]$ 
spectators synchronously" (p. 2087). Put differently, the various "articulatory modalities of audio-visual staging" (p. 2085) perceptively merge to and within expressive gestalts - expressive gestalts that spectators are assumed to perform through bodily expressions in their process of perception or expressive gestalts that resonate in the experience of spectators during the reception process (an example from our case study would be the experience of a movement directed towards a goal that is being stopped and breaks off, thus evoking the feeling of being excluded). As articulatory modalities of audio-visual staging, we address film techniques, such as camera movement, montage, sound design, acting, visual composition, etc. ('visual composition' targets the visual arrangement and staging of figures and objects, the use of color and light, graphic forms, etc., and is closely related to the term 'mise-en-scène' (BORDWELL \& THOMPSON, 2008, p. 112-157)). However, the concept of movement, which is implied in the concept of expressive movement, is not a technical one. As Gilles Deleuze (1997, p. 1) in The Movement-Image - the first of his two famous books on cinema - writes with reference to Henri Bergson: "you cannot reconstitute movement with positions in space or instants in time, that is, with immobile sections [coupes]. [...] thus each movement will have its own qualitative duration."

Concerning their overall macro-analytic structure, audio-visual forms - be they a 90-minute fiction film or a 6-minute-report within a political TV broadcast - are compositions of various cinematic expressive movements. For analytical reasons, we therefore segment audio-visual media data into cinematic expressive movement units (emu). When it comes to one's perceptive experience, however, "[e]xpressive movements are not distinct and isolated temporal units, but interact dynamically with each other" (SCHERER, GREIFENSTEIN \& KAPPELHOFF, 2014, p. 2088). More specifically, these interact within scenes, the next-in-size compositional unit of audiovisual presentational forms. That is to say that, with regard to expressivity, the sequential order of expressive movements is relevant as well, because expressive movements transform into temporally unfolding scenes. From this perspective, a scene can be addressed as more than a mere thematic unit (e.g., the thematic focus of the TV report's first scene is "Introducing the successful consultants"). A scene can also be addressed as a composition that consists of at least one, but often several, expressive movement units, "creating an affective course that the spectators go through experientially by 
watching it" (SCHERER, GREIFENSTEIN \& KAPPELHOFF, 2014, p. 2088; see also Kappelhoff \& Bakels, 2011).

It is the reconstruction of such an experience, such a kind of 'feeling', which our analysis of cinematic expressive movement targets - an immediate affection through the dynamic orchestration of audio-visual compositions as temporally-organized forms of movement experience (KAPPELHOFF, 2004). Such audio-visual gestalts capture processes of unfolding expressivity. Moreover, as the analyses will show, they frame and ground metaphoric meaning within a course of affective experiences. In the political magazine under analysis in this study, these time segments range from approximately 15 to 40 seconds.

\section{(B) Activation of metaphoricity}

In a second step, we consider how the audio-visual composition of the expressive movement units is related to the verbal part of the composition, paying particular attention to metaphoric expressions. In other words, we consider the interplay between what is being said and how this is being staged audio-visually. To give an example from our case study (verbal metaphoric expressions and their context are marked by underlining): while a voice-over is saying, "Business runs brilliantly" ("Die Geschäfte laufen glänzend"), a group of consultants is lifting sparkling glasses of champagne. Here, the sparkling glasses of champagne present the verbalized source domain of shimmering diamonds, and with this visual presentation of the metaphoric source domain, a highly specific sensory-motor experience of how "brilliant" businesses feel like is being evoked. This type of multimodal presentification of metaphoric source domains is what Müller terms "activation of metaphoricity" (MÜLLER, 2008a, b; MÜLLER \& TAG, 2010).

Due to a specific interest in sensory-motor qualities of verbal metaphoric expressions, the analyses provide translations that are as literal as possible. For example, "abgehoben" is translated as "being lifted", while the, figurative English translation for "abgehoben sein": "to have one's head in the clouds" is only given as a further explanation. Even though in this case the figurative translation of the verbal metaphoric expression would be relatively close to the literal one (because "clouds" also alludes to the direction along a vertical axis), the specific experiential dimensions and foci are different.

It is important to note that when analyzing the activation of metaphoricity, the time segments examined here range from single shots to shorter montage sequences. 
As mentioned above, the perspective and analytical procedure presented herein differs from what a CMT approach would typically focus on. According to this study's two-step analysis, the intention is not to examine the data to search for a meta-structure, such as a conceptual metaphor of the type SuCCESS IS Up, FAILURE IS Down. Rather, this examination starts from the bottom up and remains close to the experiential level of the data. In this light, what is reconstructed are metaphoric mappings from the experiential qualities staged in each and every scene. This allows to formulate emergent metaphoric meanings not within a typical " $\mathrm{A}=\mathrm{B}$ " structure, but rather by spelling them out in descriptive sentences, which include both experiential qualities as well as metaphoric conceptualizations. Metaphor emergence is indicated by small letters in italics, while overall metaphoric themes evoked by those emerging metaphors are represented by CAPITAL LETTERS IN ITALICS.

This procedure allows to exemplify in great detail how the interplay between the audio-visual composition and the verbal is orchestrated and how, through this interplay, metaphoric meaning is activated as embodied and dynamic conceptualization. The term embodied includes, on the one hand, the experiences of the metaphoric source domains that come with the activation of metaphoricity and, on the other hand, the embodied sensorymotor qualities that are staged in the cinematic expressive movement units.

Furthermore, this interdisciplinary analysis unravels the dynamic character of metaphoric mappings that begin from experience: something is experienced and understood in terms of something else. This makes it possible to document how metaphoric meaning emerges dynamically over the course and along with the flow of the audio-visual composition. Consequently, it is argued that metaphoric mappings in audio-visual data are also dynamic:

In audio-visuals the metaphoric mapping process only secondarily can be about characteristics that two conceptual domains share 'as such', like Conceptual Metaphor Theory claims. Instead, we propose that metaphoric meaning in audio-visuals primarily is arising and unfolding in a situated manner. The respective language and media use itself thus provides the reference frame that is significant in the first place. [...] Because of the dynamic and constructive view on metaphoricity we speak of a mapping in time. We understand mapping to dynamically create two present realms, and to bring them together in an unfolding process due to which one sheds light on the other. Mapping as term 
thus is not meant to find already established similarities in semantic fields or conceptual domains beyond a situated media context, but as making interactions possible, constructing similarities ad hoc through images, sensory qualities, or motives. [...] Notably, the mapping of those realms does not primarily build upon assumed similarities, but grounds in relations evoked by the concrete audio-visual context. (SCHMITT, GREIFENSTEIN \& KAPPELHOFF, 2014, p. 2104-2105)

\section{How audio-visual metaphors make winning and losing in the financial crisis feel}

To illustrate our view on audio-visual metaphors as embodied and dynamic conceptualizations rooted in experience, further detail concerning the analysis of the political TV report on the financial crisis will be presented below.

One overall metaphoric theme orchestrates the report as a whole: WINNING AND LOSING ARE EXPERIENCED AND UNDERSTOOD AS OPPOSITIONS OF MANY KINDS. A very prominent opposition mentioned above is: winning is experienced and understood as being up and losing is experienced and understood as being down. But there are more oppositions that the orchestration of the report connects with winning and losing. While winning in the financial crisis is staged as being lifted and $u p$, the report also connects this audio-visually with a range of specific experiences: with cohesion, being inside, excluding the outside, moving forward quickly and straight. Being a loser in the financial crisis, on the other hand, is staged as falling and being down and is audio-visually connected with being outside and excluded, and with stopping to move.

It is important to note that those further oppositional experiential qualities described in the metaphor formulation are the qualities of the report's cinematic expressive movements. They are the experiential grounding for the 'winners' and 'losers': e.g., winners are staged as being 'closed and inside', and losers not only are filmed in outside locations, but are staged as being 'excluded'. Thus, the experience of actually 'being outside' (standing outside a door of a bank, not being allowed to enter) becomes the experiential ground for a metaphor of feeling 'excluded' from the winners to emerge. Put differently, the activation of metaphoricity that is performed by the interplay of verbal metaphoric expressions and audio-visual images is grounded in these staged experiential qualities of winners and losers. 
In the following section, a detailed analysis of the first two scenes will illustrate how metaphoric conceptualizations of winning and losing emerge from activated source domains and from the flow of experience modulated by the composition of cinematic expressive movements. This is intended to further illustrate the experiencing and understanding of audio-visual metaphors. In a second step, an analysis of the overall metaphoric structure of the TV report will document how this embodied metaphoric meaning in fact orchestrates the entire report metaphorically.

\subsection{Emergent metaphoric meaning: the first two scenes}

Concerning the thematic structure, the first scene introduces outplacement consultants as winners of the banking crisis. A group of consultants is shown, celebrating a successful business by holding a champagne reception in their office. After a few statements from the consultants, a voice-over shortly sums up the basics of their business idea named 'outplacement'. This is done right before Eberhard von Rundstedt (the head of the consultants) comments on the suitability of outplacement for bank managers who have lost their jobs in the crisis. The second scene introduces and directly focuses on a further group of losers of the crisis: small investors. A group of them is shown outside the door of the Frankfurt branch office of the Kaupthing Bank, which had its bank accounts blocked, leading some of the small investors to lose their lifetime savings. The men are not allowed to enter the bank. Only through an intercom do they shortly communicate with a bank employee.

With regard to its expressivity, the first scene's introduction of the successful consultants as winners of the banking crisis is a composition of three expressive movement units (i.e., three movement gestalts), in other words, the scene involves three forms of movement experience: (1) cohesion, (2) fragmentation, and (3) resting and being inside. In this way, scene one unfolds experiential qualities that connect the successful bank consultants with experiences of cohesion, proximity, resting and being inside. Scene two (focusing on the losers) stages a rather contrasting experience, this time realized by the one (and only) expressive movement unit: an experience of being outside and excluded.

Concerning the activation of metaphoricity, scene one elaborates on the contrasting experiential source domains highlighted in the introduction of the winners as being 'up' ("lifted monetary caste") and losers as being 'down' ("bankers will fall”), but the audio-visual composition also orchestrates 
specific sensory-motor experiences of these source domains. By articulating specific kinds of movement and spatial orientation along a vertical axis, the audio-visual composition spells out a specific manner of experience; it shows how being a winner and up, as well as being a loser and down, actually feels. In scene one, winning and losing are staged differently in two of the three expressive movement units (emu) mentioned above: being a winner is staged with upward movements (emu 1), failing or losing is staged with downward movements (emu 3), being a (winning) star is staged as being separated and up (emu 3). By presenting outplacement as a solution for the bankers, having lost their job in the crisis, the second expressive movement unit shifts thematically to a somewhat different topic. Anyhow, since the focus of this paper is on the semantic opposition of winning and losing, we will not discuss this any further in our present analysis, but will focus only on the expressive movement units 1 and 3 of scene one.

By contrast scene two, performed within one expressive movement unit, presents the losers (the small investors) as being and looking down; therefore, losing is staged as being and looking down. Here the audio-visual composition involves activating and vitalizing metaphoric meaning. By staging one highly particular way of perceiving the source domain and by connecting it with semantic oppositions on the metaphoric verticality axis, specific kinds of embodied conceptualizations of the financial crisis are orchestrated and made available to the spectator.

The following micro-analyses provide a more detailed outline of how these experiential qualities and the source domain vitalizations emerge over time and how metaphoric meaning is a process of meaning making grounded in a flow of experiences.

\subsubsection{Winning feels up and comes with a sensation of cohesion}

In the beginning of the expressive movement with which the first scene begins, one can see groups of people standing around small tables, all directed towards a shared center, an interior, thus forming a kind of 'closed circle'. The camera approaches them again and again, the repeated camera movement contrasting and highlighting the rather static quality of the circular formations. This movement transforms into a calmer mediumclose-shot montage of smiling faces - faces that appear like a variation of the circular group formations - showing the group members individually. This movement composition merges to an expressive movement unit and evokes an experience of cohesion. 


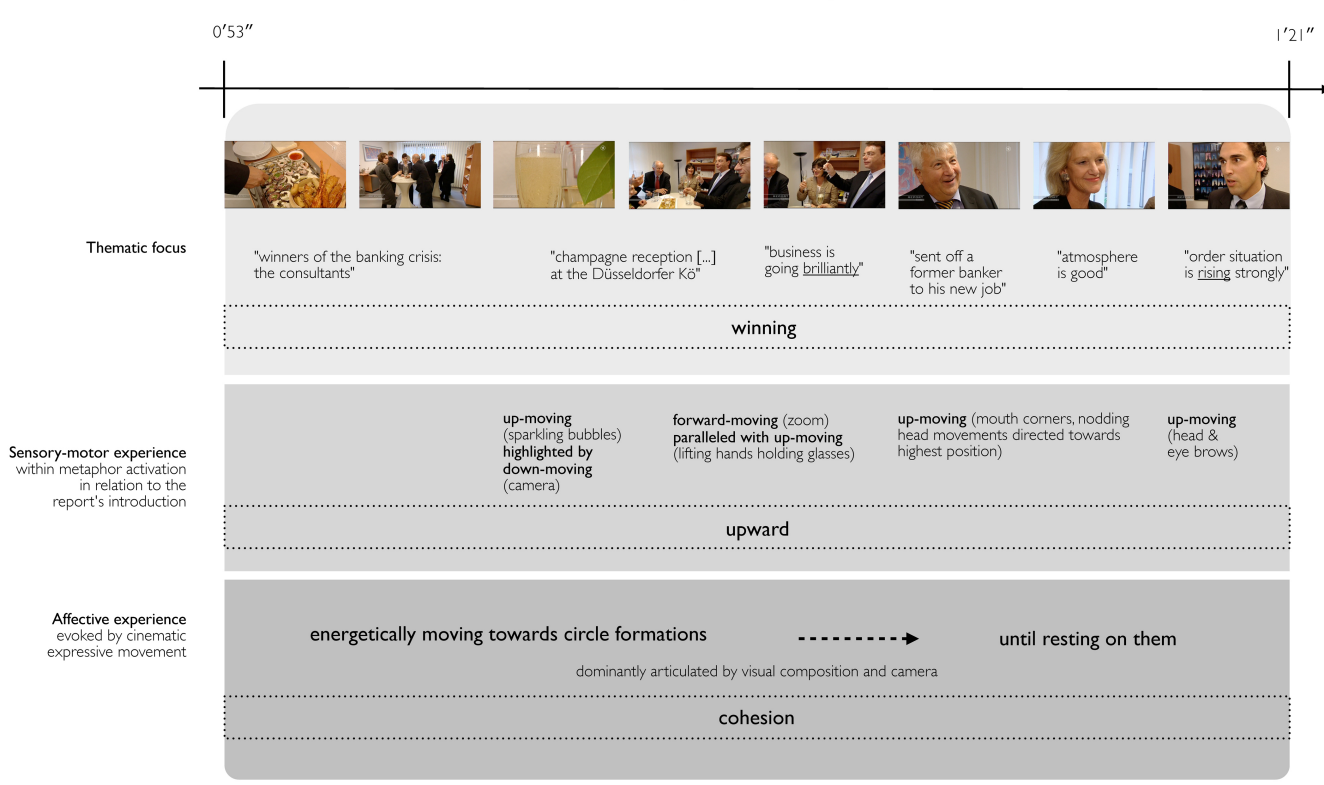

Source: figure by Christina Schmitt (including screenshots from Report Mainz)

Figure 1: Analysis of the TV report on the financial crisis (Report Mainz, ARD, October 20,2008 ) - expressive movement unit 1 (scene 1): winning is grounded in a sensation of cohesion and is correlated with many sensory-motor experiences or sensations of 'up'.

Within the unfolding of this first cinematic expressive movement of scene one, that is, within the experience of cohesion, an activation of metaphoricity takes place, connecting winning with upward movements. The report begins with a voice-over, allocating the people who are seen clearly on the side of the winners:

"They are part of the winners of the banking crisis: the consultants of the company Von Rundstedt Human Resources Partners."

['Sie gehören zu den Gewinnern der Bankenkrise: die Berater der Firma Von Rundstedt Human Resources Partners."] (transcribed from Report Mainz)

What can be seen while listening to this utterance are accurately arranged canapées on trays followed by a camera move towards a group of business people who are drinking champagne. A close up of a sparkling glass of champagne - already a symbol for celebrating success - is then 
staged by a downward camera movement, highlighting the upward motion of the champagne bubbles. The next shot shows the consultants lifting their sparkling glasses to celebrate their success. A zoom-in camera movement intensifies the movement quality of the lifting of their glasses while the voice-over states: "business is doing brillantly" ("die Geschäfte laufen glänzend"). The first expressive movement ends with a montage of three medium close shots of smiling consultants (which implies raised mouth corners as much as seclusion and cohesion of the group of winners), the last one mentioning the situation of a strong rising order while at the same time raising his head, eyes, and eyebrows.

To sum up, the staging brings together winning with specific kinds of upward experiences (sensations of 'up' and activation of a specific experiential source domain) on the one hand, and an experience of seclusion and cohesion and of being inside (composition of expressive movement) on the other hand. This alignment of seclusion, of cohesion, and of being inside with upward movements thus represents the grounding of metaphoric meaning in sensory experiences.

\subsubsection{Opposing experiences: winning comes with the sensation of being up, inside and at rest, losing with falling into the deep and with hiding}

The expressive movement that completes the first scene begins in a quality of smooth dynamics: a mumbling of soft voices and a short montage of circular formations (canapées in circular formations, consultants at a round table) and vertical movements (by camera and hand gestures). By shifting the action space (from the champagne reception to an office), this smooth and rather relaxed dynamics transforms into a sensation of calmness and rest: With a static and fairly long take, the camera rests on von Rundstedt, who is sitting in a chair, emphasizing his voluminous body through a low angle shot. The sound quality, which had previously been fairly dry, parallels this by reverberating von Rundstedt's deep voice, making it sound voluminous, thereby evoking the impression of a physical presence in a closed space. The composition of the third expressive movement unit in scene one forms an audio-visual gestalt, which brings about an experience of being and resting inside. 


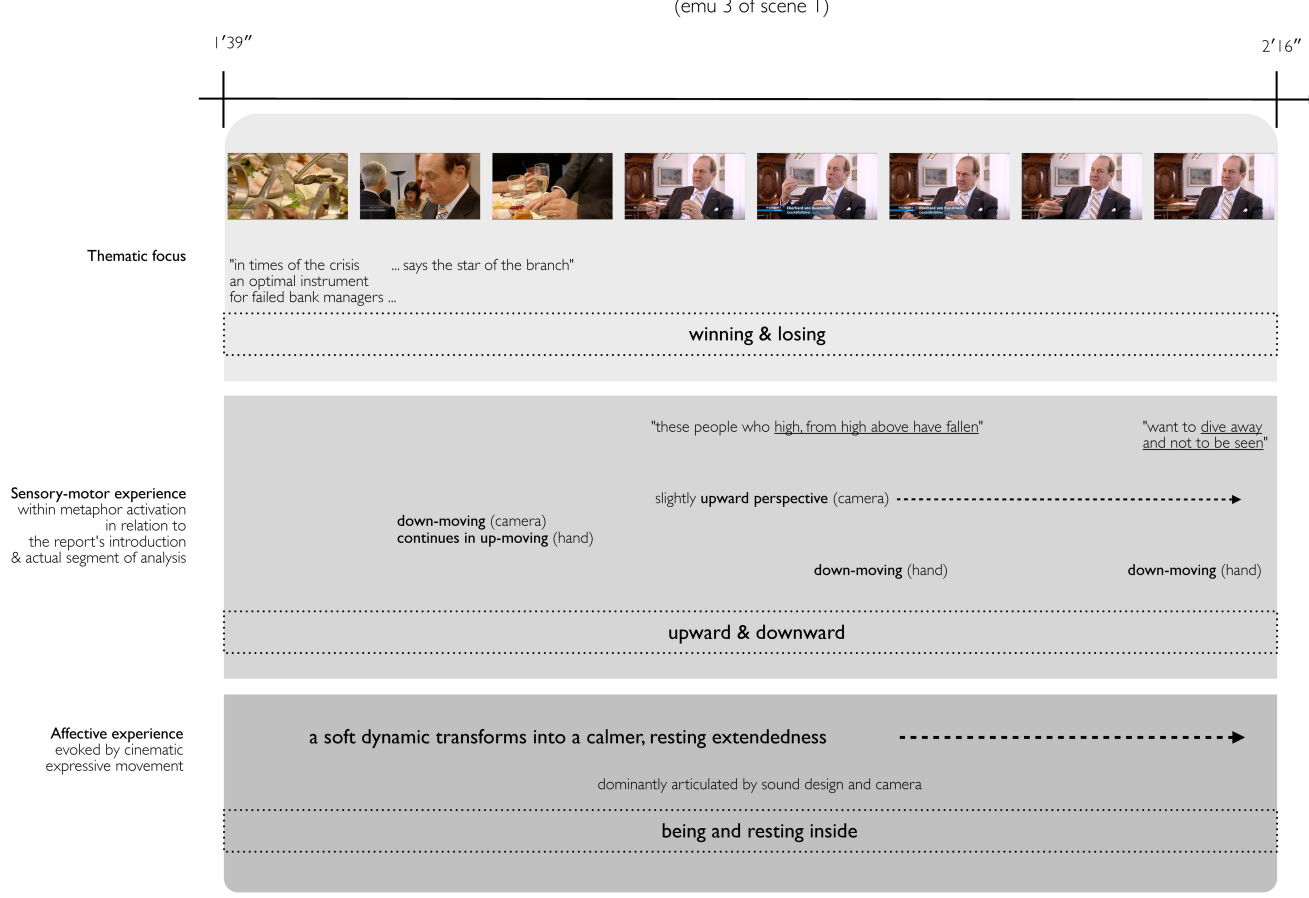

Source: figure by Christina Schmitt (including screenshots from Report Mainz)

Figure 2: Analysis of the TV report on the financial crisis (Report Mainz, ARD, October 20, 2008) - expressive movement unit 3 (scene 1): winning comes with a sensation of being inside and at rest, and with sensations of 'up', whereas losing comes with a sensation of falling and hiding in the deep and with sensations of 'down'.

Within the unfolding of the third expressive movement unit, that is, within the experience of resting and being inside, the report orchestrates a twofold activation of metaphoricity along a vertical axis: losing is connected with falling into the deep, and hiding there and being a star is connected with being singled out and with being up. The third expressive movement entails a longer statement of Eberhard von Rundstedt on outplacement. A voice-over introduces von Rundstedt high up on the verticality axis as the star of the branch.

The audio-visual composition prepares the statement by establishing a vertical axis, directly before the space of action changes from the champagne reception to von Rundstedt's office. Here one can see the man introduced as "the star of the branch" standing together with the consultants at one of the champagne reception's tables. A medium-close-shot of his face is followed by a 
a camera movement down along his body to his hands on the table, now showing upward gesturing. In this way the verbal expression 'a star of the branch' is embedded in an experiential domain of movement along a vertical axis.

Directly after this vertical axis has been established, von Rundstedt now alone in his office - comments verbally and gesturally on the failed bank managers by connecting them with a metaphoric downward movement: "these people, who, in fact, high, from high above have fallen" ("diese Menschen, die ja hoch, von hoch oben gestürzt sind"). When von Rundstedt talks about the bank managers who have lost their jobs, who have fallen from high above, his gesturing also takes on a downward movement, highlighting the downward quality through its alignment with the downward movement of the verbal metaphoric expression. This utterance represents a kind of resumption of the introduction to the report: "many fired bankers will fall gently, if they fall," thus further developing the inherent metaphoric theme.

Later in his statement on outplacement for failed bank managers, von Rundstedt once again describes the situation of the unemployed bank managers with a verbal metaphoric expression that operates in the experiential source domain of downward movement: "... actually, they want to dive away and not to be seen" (“... sie wollen eigentlich wegtauchen und nicht gesehen werden”). These 'poor' ex-managers want to dive away and hide away. Moreover, von Rundstedt has also stopped his gesturing while saying this. As a result of the cadrage, his hands are no longer visible within the image field (i.e. on screen). In fact, they appear as if they had fallen, into the deep, into the image's off. In this light, the composition evokes the impression that the former bank managers - embodied in the downward movement of the hands and as a consequence of it - have disappeared into some invisible deep.

Von Rundstedt himself, on the contrary, is staged in a discrete manner upon the verticality axis: the camera rests on the speaking and gesturing from von Rundstedt in a slightly low angle shot, which makes him subtly appear to be 'up'.

To sum up, the third expressive movement unit orchestrates an experiential opposition between winning and losing: being one of the winners comes with a sensation of being inside and at rest (composition of expressive movement) and with experiences or sensations of 'up' (activation of a specific experiential source domain), whereas losing involves experiences of falling and hiding in the deep, thus coming with experiences or sensations of 'down' (activation of a specific experiential source domain). 


\subsubsection{Losing feels down and comes with a sensation of exclusion}

In the beginning of the cinematic expressive movement that orchestrates scene two, the emphasis concentrates on motion itself. With a long tracking shot, the camera begins to move along with the protagonists - the small investors - and the camera movement displays walking as a group movement. This movement, although continuing for quite a while, eventually transforms (due to the visual composition) into a tunnel-shaped goal orientation of moving forward, when the small investors are shown as walking along between house walls. The length of this shot underlines the continuous movement of both the protagonists and the camera. In the closure, a shot-reverse shot montage breaks off the former continuous movement. Next, one hears the sound of a discarnate voice sounding from the intercom system and sees the wall of a house. This audio-visual image is contrasted several times with faces staring at the intercom in the wall, and the montage establishes a kind of harsh halt. Thus, the joint movement of the group is directed towards that moment, when the group stops in front of a house wall, a movement that is directed towards a goal but is being stopped and breaks off. The composition of this audio-visual gestalt evokes an experience of being outside and excluded.

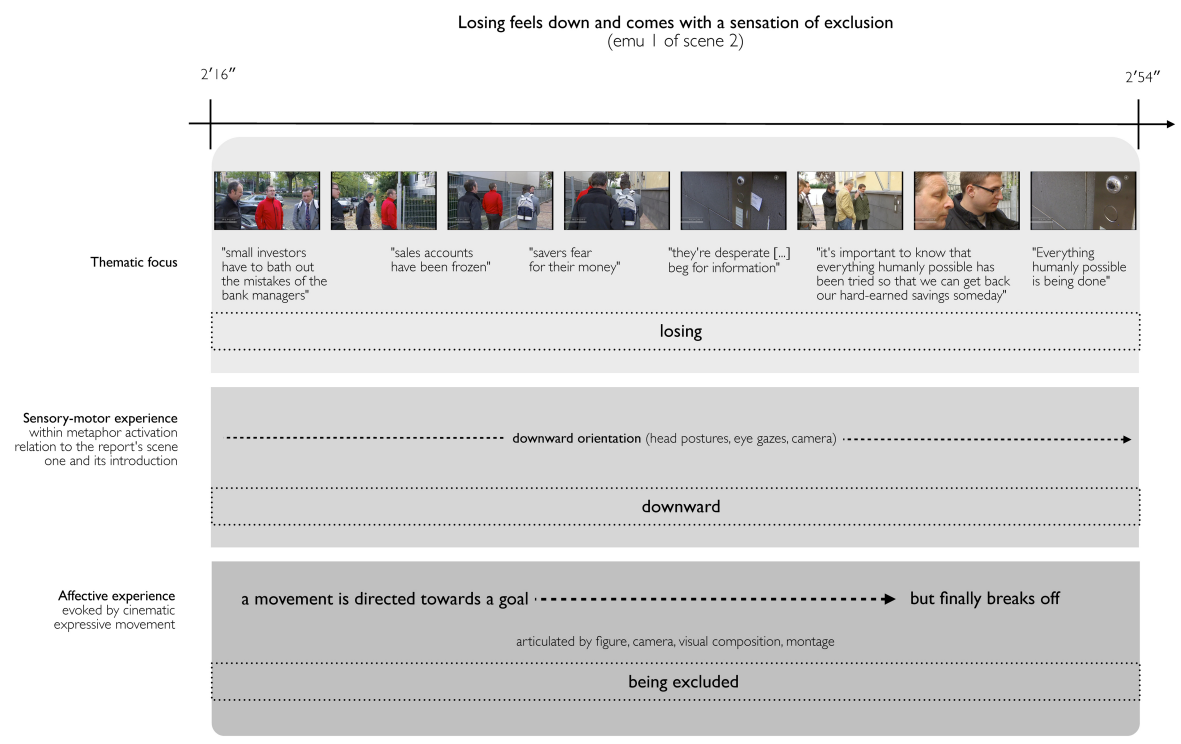

Source: figure by Christina Schmitt (including screenshots from Report Mainz)

Figure 3: Analysis of the TV report on the financial crisis (Report Mainz, ARD, October 20,2008) - expressive movement unit 1 (scene 2): losing comes with a sensation of 'down' and of being excluded. 
Within the unfolding of this expressive movement, that is, within the experience of being excluded, an activation of metaphoricity takes place by which losing is perceived as being and looking down. Verbally, this scene opens with a voice-over comment on the preceding statement of von Rundstedt, with which the previous scene had just finished: "the small investors have (lit.) to bath out (fig.) to carry the can for the errors of the bank managers" ("die Kleinanleger [müssen] die Fehler der Bankmanager ausbaden"; "ausbaden" is a non-activated metaphoric expression here). While one hears that it is the fate of the small investors to pay for the faults of the banks, one can see the small investors walking to a door down at a house; the camera joins their walk. It is the door of the Frankfurt branch office of the Icelandic Kaupthing Bank - the bank that has "frozen" the small investor's sales accounts and that makes them "desperate" and "fearing for their money", as the voice-over explains, thereby elaborating on the realm of losing. The combination of walking between the house walls and the camera movement both end in a downward position: when reaching the door, everything is directed downwards, since the posture of the heads, the eye-gazes, as well as the camera perspective are all directed downwards, pointing to the intercom. This downward direction continues in the following short montage, which stages a conversation between the voice from the intercom and the small investors. Their request for information and dialog fails. It is stifled by the intercom's slightly distorted voice, which is raised while showing an image of a house-wall - a faceless, inhuman voice. In essence, this voice only echoes the small investors' utterances, turning the conversation into absurdity, and once again demonstrates the small investors' losses:

(small investor) "Yeah, for us, it is just important to know that everything humanly possible has been done so that we can get back our hard-earned savings one day." - (intercom:) "Exactly! And this is exactly the case: everything human possible is being done."

[(small investor) "Ja wichtig ist uns natürlich einfach nur, dass alles Menschenmögliche versucht wird, damit wir unser sauer erspartes Geld wieder irgendwann bekommen können." - (intercom) "Ganz genau. Und genau das ist auch der Fall: Es wird alles Menschenmögliche getan."] (transcribed from Report Mainz) 
The composition connects different ways of experiencing a sensation of 'down' with the losers of the crisis. Note that, in this expressive movement unit, 'down' is not verbally present. This means that the activation of metaphoricity observed here is not one that rests upon a verbal metaphoric expression articulated in scene two. Rather, the activation emerges from the audio-visual composition and is connected temporally to the previous scene one. It further specifies and concretizes the experiential realm of losing in terms of a sensation of 'down'.

The orchestration of the expressive movement unit that constitutes the second scene of the report thus evokes a sensation of being excluded while the experience of being and feeling down for those specific losers of the big financial crisis is specified by the audio-visual activation of metaphoricity.

\subsection{Temporal dynamics of metaphoricity: the report and its metaphoric theme}

The TV report is a beautiful illustration of the inherently temporal nature of metaphoric meaning and documents to what extent metaphoricity is dynamically emerging from audio-visual compositions. What the spectators see are not concatenations of single metaphoric instantiation in words, moving images, or sounds. Rather, there is an intricate interplay between the expressive qualities that emerge from the composition of cinematic expressive movements and the activation of experiential source domains of either verbally introduced and/or audio-visually evoked metaphoric mappings, all providing highly specific embodied experiences of a metaphoric theme that connects winners and losers not only with being 'up' or 'down', respectively, but also with further opposing experiential qualities. In this light, the following section sketches out how the metaphoric theme WINNING AND LOSING ARE EXPERIENCED AND UNDERSTOOD AS OPPOSITIONS OF MANY KINDS dynamically evolves and thus predominantly structures the audio-visual composition of the report as a whole (see also Figure 4). 


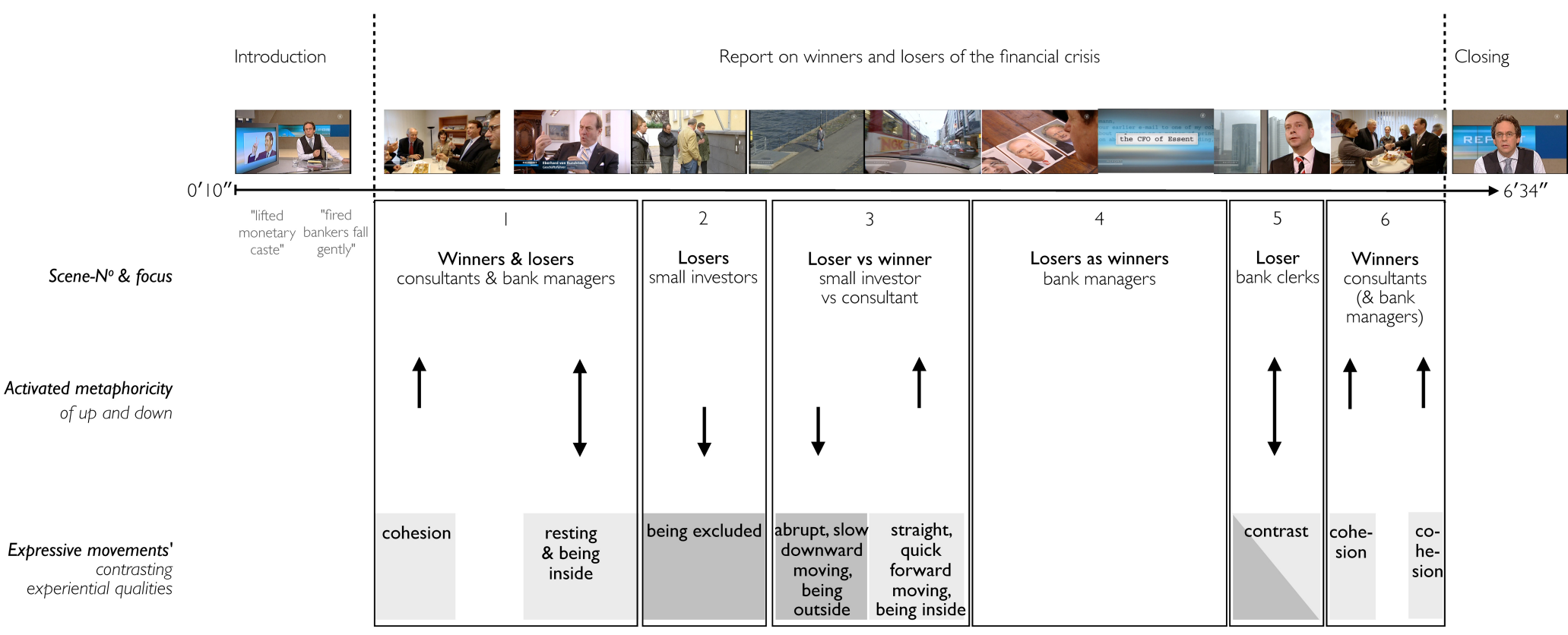

Source: figure by Christina Schmitt (including screenshots from Report Mainz)

Figure 4: Analysis of how the metaphoric theme of WINNING AND LOSING IS EXPERIENCED AND UNDERSTOOD AS OPPOSITIONS OF MANY KINDS evolves and provides the predominant dynamic structure of the entire TV report on the financial crisis (Report Mainz, ARD, October 20, 2008) 
As can be seen in the analyses of scene one and two above, metaphoricity - first set up in the introductory statements - now fully emerges and unfolds: being a winner is experienced and understood as being up, while a loser is experienced and understood as being down. Moreover, we have suggested that, due to the audio-visual images' expressive movements, further experiential qualities emerge that have not been mentioned in the introduction: being a winner unfolds within experiences of (group) cohesion and of resting and being inside, while being a loser unfolds within the experience of being excluded. Obviously, this means much more than just the fact that the action spaces of winners are interior spaces (e.g., rooms of an office), while those of the losers are exterior spaces (e.g., the street outside a bank building that the small investors are not allowed to enter). The point is that the composition of the cinematic expressive movements in these first two scenes not only orchestrates this interior-exterior antagonism, but also turns it into a movement experience.

This embodied conceptualization of losers and winners as an experiential opposition culminates towards the middle of the overall report, when scene three - in a highly symmetrical compositional structure - confronts a small investor with a consultant. The staged experiencing of an opposition here is highly complex: an abrupt, slow, downward movement and being outside (loser) is confronted with a straight, quick forward movement (winner). Of particular interest is that the experience and the sensation of 'down' are now the main quality of an expressive movement itself, rather than a quality of a depicted pose or of a camera's short shot perspective.

Scene four follows this climax and brings an unexpected turn of the report's metaphoric rhetoric. Unexpected, because, similar to what occurs at the end of scene one, the topic now shifts to a very specific group of losers within the financial crisis - the bank managers themselves. While at the end of scene one their failing was connected to a drastic experience of downwardness (i.e. as a falling from high up), what is highlighted now is the problem of turning failure in the financial crisis into success. Interestingly, this is performed among others, with a staging through a montage of upward movements, particularly of zooms and camera movements, as well as with an upward gesture of the former German Minister of Finance. However, it would fall much too short to conclude (due to the previous scenes) that upward movements in general are connected to success and winning. Rather, at this point of the report, these movements dynamically map with what is verbally articulated, since the voice over presents bank managers who have 
lost their jobs as "hoch risikobehaftet" - "highly fraught with risk". Put differently, the upward movements together with the verbal now articulate a metaphorical spatializing of risk. This calls attention to a very basal but essential facet of audio-visual images: Audio-visual articulations, like a camera movement or perspective, do not refer to conventionalized, fixed meanings (there are no audio-visual 'dictionaries'); audio-visual 'meanings' are highly context sensitive and, from our point of view, only graspable within highly dynamic, emerging embodied complexes.

It is within the report's last two scenes that the metaphoric structure, as emerged and established in the first three scenes of the report, is taken up again. In scene five, the focus stays with bankers as losers of the financial crisis. Nevertheless, it shifts from failed managers to bank clerks, whose positions were laid off on a massive scale, as the voice-over states; a staging of contrast dominates this scene. Initially, the topic 'laid-off bank clerks' is staged by situating these losers at the lower end of a vertical axis: the verbal metaphoric expression produced in the voice-over "down, it [i.e., the situation] looks totally different" comes along with an upward camera movement resulting in an extreme low angle shot of a bank, followed by a statement of a bank employee representative commenting on the problems of these bank clerks. This is staged by a highly symmetrical, two-part visual composition, opposing the representative by a racking focus with bank towers. Scene six, finally, establishes a closing frame for the overall report by returning to the consultants as winners, once again taking up the staging of the experiential quality of 'cohesion' as established in the first scene.

It can therefore be concluded, that the overall structure of the report is a dynamically emerging experience of opposing qualities and experiences that are connected metaphorically with the group of winners and losers of the banking crisis, respectively.

\subsection{Summary}

This interdisciplinary analysis of audio-visual metaphors in a German TV report on the financial crisis has revealed that there is one governing metaphoric theme that orchestrates the TV report on winners and losers of the financial crisis: WINNING AND LOSING ARE EXPERIENCED AND UNDERSTOOD AS OPPOSITIONS OF MANY KINDS. This metaphoric theme emerges and is grounded in highly specific realms of audio-visually modulated experiences: 
Winning in the financial crisis is experienced and understood as being lifted and up, closed and inside, excluding the outside, moving quick, straight, and unaffected.

Losing in the financial crisis is experienced and understood as falling and being down, outside, and excluded, as stopping to move.

Several of the sensory qualities in these metaphoric formulations describe the experiential and affective qualities of the report's cinematic expressive movements, through which winners and losers are staged. These experiential qualities are not verbalized, nor are they part of a linguistic source domain of a verbal metaphoric expression: they are evoked by the composition of the audio-visual 'movement-images'. On the other hand, the main metaphoric opposition - winning as being lifted and up, losing as falling and being down - is introduced and activated by the interplay of verbal metaphoric expressions and audio-visual images. This opposition is first mentioned verbally in the introduction to the report and announces the metaphoric opposition that will emerge to the 'leitmotif' of the report's composition. The source domains are activated through different forms of staging sensations of 'up' and 'down', respectively. At the same time, they come to be grounded in the unfolding of the cinematic expressive movements' experiential qualities.

\section{Conclusion: Understanding through experience}

In a nutshell, the conclusion can be formulated as follows: Audio-visual metaphors are dynamic forms of meaning making and are affectively grounded in the sensory experiences of the cinematic expressive movements. The analysis of a news report was meant to illustrate that audio-visual metaphors cannot sufficiently be accounted for as static instantiations of conceptual metaphors (HAPPY IS UP, SAD IS DOWN) or image schemas (verticality scheme). Rather they should be considered as a complex processes of meaning making in which experiences of source domains are intricately interwoven with the experiential qualities of cinematic expressive movements, at times even merging one into the other. In other words, metaphoric meaning in audiovisual compositions should be considered as dynamic, as emergent over time, and as grounded in embodied experiences, which are made available by activated source domains and/or by cinematic expressive movements. 
Hence, metaphoric meaning should be considered to be more of a process than a product or a stable knowledge structure (GIBBS, 1993; EVANS, 2009) and as such it is in constant flow. This position runs in line with Evans, who points out that:

[...] knowing that conceptual metaphors have psychological reality does not, in and of itself, facilitate an account of figurative meaning construction. [...] conceptual metaphors are relatively stable knowledge structures, while meaning is a flexible, open-ended, and dynamic process. (EVANS, 2009, p. 91)

Audio-visual metaphors must be conceived of as emergent, experientially-grounded forms of meaning making. For the TV report on the financial crisis, metaphoric meaning concerns thus the dynamic emergence of embodied conceptualizations over the course of the entire report, grounded in the sensations of sensory experiences, which is what we tentatively call understanding through experience.

Such a stance alludes to Mark Johnson's "meaning of the body” (2007). When we as spectators watch such a political report, the processes in which we make sense of it are embodied, our meaning making resides in the actual bodily experiences modulated by the cinematic expressive movements and the metaphors that are grounded within them or emerge from them. Please note, however, that this does not involve assumptions concerning the actual psychological and physiological processes that spectators go through. As much as we, as human beings, immediately perceive the expressivity of a smiling face, we, as spectators, perceive the audio-visual compositions of cinematic expressive movements and the embodied metaphoric conceptualizations arising from them (KAPPELHOFF \& MÜLLER, 2011; KAPPELHOFF \& GREIFENSTEIN, in prep.). In this manner, our work on audio-visual metaphors is a proposal to empirically reconstruct how meaning is grounded in bodily experience:

According to the view I am developing, meaning is grounded in bodily experience; it arises from our feeling of qualities, sensory patterns, movements, changes, and emotional contours. Meaning is not limited only to those bodily engagements, but it always starts with and leads back to them. Meaning depends on our experiencing and assessing the qualities of situations. (JOHNSON, 2007, p. 70) 


\section{References}

BORDWELL, D.; THOMPSON, K. Film Art. An Introduction. New York: McGraw-Hill, 2008. 505p.

BRANDT, L.; BRANDT, P.A. Cognitive poetics and imagery. European Journal of English Studies, London et al., v. 9, n. 2, p. 117-130, 2005a.

BRANDT, L.; BRANDT, P.A. Making sense of a blend: A cognitive-semiotic approach to metaphor. Annual Review of Cognitive Linguistics, Amsterdam et al., v. 3, n. 1, p. 216-249, 2005b.

BÜHLER, K. Ausdruckstheorie. Das System an der Geschichte aufgezeigt. Stuttgart: Fischer, 1968. 244p.

CAMERON, L. Metaphor and reconciliation. The discourse dynamics of empathy in post-conflict conversations. New York: Routledge, 2011. 208p.

CAMERON, L.; MASLEN, R. Identifying metaphors in discourse data. In: CAMERON, L.; MASLEN, R. (Ed.). Metaphor analysis. Research practice in applied linguistics, social sciences and the humanities. New York: Equinox, 2010. p. 97-115. COËGNARTS, M.; KRAVANJA, P. From thought to modality: A theoretical framework for analysing structural-conceptual metaphors and image metaphors in film. Image [\&] Narrative, Leuven, v. 13, n. 1, p. 96-113, 2012.

CRISP, P. Between extended metaphor and allegory: is blending enough? Language and Literature, London, v. 17, n. 4, p. 291-308, 2008.

DELEUZE, G., Cinema 1. The movement-image. Minneapolis: University of Minnesota Press, 1997. 264p.

DIJKSTRA, K; EERLAND, A.; ZIJLMANS, J.; POST, L. S. Embodied cognition, abstract concepts, and the benefits of new technology for implicit body manipulation. Frontiers in Psychology, Lausanne, v. 5, art. 757, 2014.

EVANS, V. Metaphor, lexical concepts, and figurative meaning construction. Cognitive Semiotics, Bern et al., v. 5, n. 1-2, p. 73-107, 2009.

FAHLENBRACH, K. Embodied spaces: Film spaces as (leading) audio-visual metaphors. In: ANDERSON, J. D.; FISHER ANDERSON, B. (Ed.). Narration and Spectatorship in Moving Images. Cambridge, MA: Cambridge Scholars Press, 2007. p. 105-124.

FAHLENBRACH, K. Audiovisuelle Metaphern. Zur Körper-und Affektästhetik in Film und Fernsehen. Marburg: Schüren, 2010. 304p.

FORCEVILLE, C. J. Multimodal metaphor in ten Dutch TV commercials. Public Journal of Semiotics, N.P., v. 1, n. 1, p. 15-34, 2007.

FORCEVILLE, C. J.; URIOS-APARISI, E. (Ed.). Multimodal metaphor. Berlin/ New York: Mouton de Gruyter, 2009. 458p. 
GIBBS Jr., R. W. Process and products in making sense of tropes. In: ORTONY, A. (Ed.). Metaphor and thought, $2^{\text {nd }}$ ed., Cambridge: Cambridge University Press, 1993, p. 252-276.

GIBBS Jr., R. W. Why do some people dislike Conceptual Metaphor Theory? Cognitive Semiotics, Bern et al., v. 5, n. 1-2, p. 14-36, 2009.

GREIFENSTEIN, S.; KAPPELHOFF, K. The discovery of the acting body. In: MÜLlER, C.; CIENKI, A.; FRICKE, E. et al. (Ed.). Body-Language Communication: An international handbook on multimodality in human interaction, v. 2, Berlin/New York: De Gruyter Mouton, 2014. p. 2070-2080.

JOHNSON, M. The meaning of the body. Aesthetics of human understanding. Chicago: University of Chicago, 2007. 308p.

KAPPELHOFF, H. Matrix der Gefühle. Das Kino, das Melodrama und das Theater der Empfindsamkeit. Berlin: Vorwerk 8, 2004. 340p.

KAPPELHOFF, H.; BAKELS, J.-H. Das Zuschauergefühl. Möglichkeiten qualitativer Medienanalyse. Zeitschrift für Medienwissenschaft, Zürich, v. 5, n. 2, p. 78-95, 2011.

KAPPELHOFF, H.; MÜLLER, C. Embodied meaning construction. Multimodal metaphor and expressive movement in speech, gesture, and feature film. Metaphor and the Social World, Amsterdam, v. 1, n. 2, p. 121-153, 2011.

KAPPELHOFF, H.; GREIFENSTEIN, S. Audiovisual metaphors - Embodied meaning and processes of fictionalization. In: FAHLENBRACH, K. (Ed.). Embodied Metaphors in Film, Television, and Video Games: Cognitive Approaches. New York/London: Routledge, in prep., to appear in 2015.

LAKOFF, G.; JOHNSON, M. Metaphors we live by. Chicago: University of Chicago, 1980.242p.

LESSING, G. E. Hamburgische Dramaturgie. Berlin: Aufbau, 1954. 548p.

LUODONPÄÄ-MANNI, M.; VIIMARANTA, J. Metaphoric expressions on vertical axis revisited: An empirical study of Russian and French material. Metaphor and Symbol, New York (NY) et al., v. 25, n. 2, p. 74-92, 2010.

MÜLLER, C. Metaphors dead and alive, sleeping and waking. A dynamic view. Chicago: University of Chicago Press, 2008a. 272p.

MÜLLER, C. What gestures reveal about the nature of metaphor. In: CIENKI, A.; MÜLLER, C. (Ed.). Metaphor and gesture. Amsterdam: John Benjamins, 2008b. p. 219-245.

MÜLLER, C. Reaction paper. Are 'deliberate' metaphors really deliberate. Deliberateness in the light of metaphor activation. Metaphor and the Social World, Amsterdam, v. 1, n. 1, p. 61-66, 2011. 
MÜLLER, C.; CIENKI, A. Words, gestures and beyond. Forms of multimodal metaphor in the use of spoken language. In: FORCEVILLE, C.; URIOS-APARISI, E. (Ed). Multimodal metaphor. Berlin/New York: Mouton de Gruyter, 2009. p. 297-328.

MÜLLER, C.; TAG, S. The dynamics of metaphor. Foregrounding and activation of metaphoricity in conversational interaction. Cognitive Semiotics, Berlin et al., v. 10, n. 6, p. 85-120, 2010.

MUSOLFF, A.; ZINKEN, J. (Ed.). Metaphor and discourse. Basingstoke/New York: Palgrave Macmillan, 2009. 269p.

ORTIZ, M. J. Visual manifestations of primary metaphors through mise-en-scène techniques. Image [\&] Narrative, Leuven, v. 15, n. 1, p. 5-16, 2014.

SANTANA, E.; DE VEGA, M. Metaphors are embodied, and so are their literal counterparts. Frontiers in Psychology, Lausanne, v. 2, art. 90, 2011.

SCHERER, T.; GREIFENSTEIN, S.; KAPPELHOFF, H. Expressive movements in audio-visual media: Modulating affective experience. In: MÜLLER, C.; CIENKI, A.; FRICKE, E. et al. (Ed.). Body-Language - Communication: An international handbook on multimodality in human interaction, v. 2. Berlin/New York: De Gruyter Mouton, 2014. p. 2081-2092.

SCHMITT, C.; GREIFENSTEIN, S.; KAPPELHOFF, H. Expressive movement and metaphoric meaning making in audio-visual media. In: MÜLLER, C.; CIENKI, A.; FRICKE, E. et al. (Ed.). Body-Language - Communication: An international handbook on multimodality in human interaction, v. 2. Berlin/New York: De Gruyter Mouton, 2014. p. 2092-2112.

SCHMITT, C. Embodied meaning in audio-visuals - First steps towards a notion of mode. In: WILDFEUER, J. (Ed.). Building bridges for multimodal research international perspectives on theories and practices of multimodal analysis. Bern/New York: Peter Lang, in prep., to appear in 2015.

PLESSNER, H. Die Deutung des mimischen Ausdrucks. Ein Beitrag zur Lehre vom Bewußtsein des anderen Ichs [1925]. In: DUX, G.; MARQUARD, O.; STRÖKER, E. (Ed.). Helmuth Plessner. Gesammelte Schriften, v. 7: Ausdruck und menschliche Natur. Frankfurt a.M.: Suhrkamp, 1982. p. 67-129.

PRAGGLEJAZ GROUP (2007): MIP: A method for identifying metaphoricly used words in discourse. Metaphor and Symbol, New York (NY) et al., v. 22, n. 1, p. 1-39, 2007. SEMINO, E. Metaphor in discourse. Cambridge: Cambridge University Press, 2008. 247p. STEEN, G. J.; DORST, A. G.; HERRMANN, J. B.; KAAL, A. A.; KRENNMAYR, T.; PASMA, T. A method for linguistic metaphor identification: From MIP to MIPVU. Amsterdam/Philadelphia: John Benjamins, 2010. 238p. 
WERTH, P. Extended metaphor - a text-world account. Language and Literature, London, v. 3, n. 2, p. 79-103, 1994.

WINTER, B. Horror movies and the cognitive ecology of primary metaphors. Metaphor and Symbol, New York (NY) et al., v. 29, n. 3, p. 151-170, 2014. ZINKEN, J.; HELLSTEN, I.; NERLICH, B. Discourse metaphors. In: FRANK, R. M.; DIRVEN, R.; ZIEMKE, T.; BERNÁRDEZ, E. (Ed.). Body, language and mind, v. 2: Sociocultural situatedness. Berlin/New York: Mouton de Gruyter, 2008. p. 363-386. 
